\title{
Redactioneel
}

\section{Een nieuwe start}

Voor u ligt het Tijdschrift voor feugdrecht (Tvfr), het tijdschrift voor de praktiserende jeugdrechtjurist.

De redactionele formule bij het nieuwe tijdschrift verwoordt dat luid en duidelijk als volgt: 'De doelstelling van $T v f r$ is de praktiserende jeugdrechtjurist op een overzichtelijke manier te voorzien van kwalitatief hoogwaardige informatie over actuele (juridische) ontwikkelingen en hem daarbij tevens te verwijzen naar informatie aangeboden in andere producten. $T v f r$ is zowel een signalerende als verdiepende praktijkgerichte informatiebron. Uitgangspunt is dat de inhoud van de artikelen kwalitatief hoogwaardig is en dat de artikelen oplossingen of overzichten bieden voor de praktijk van de jurist. Voor de artikelen in $T v f r$ geldt dat het Internationale Verdrag inzake de Rechten van het Kind telkens bron en ijkpunt is.'

$\mathrm{Na}$ vijf jaar als feugdrecht in de Praktijk (FIP) door het leven te zijn gegaan, is het tijdschrift overgenomen door Boom juridisch en in een nieuw jasje gestoken. Om een indruk te geven van de artikelen die onder het oude regiem verschenen, kan worden gewezen op de volgende rubrieken en onderwerpen. Veel aandacht ging uit naar de werking van de 'nieume' kinderbeschermingsmaatregelen en de Feugdwet. Daarbij gaf een overzichtsartikel inzicht in de actuele ontwikkelingen van de afgelopen twee jaren en werd in twee andere artikelen aandacht besteed aan de aanvaardbare termijn bij gezagsbeëindiging en de bescherming van de persoonsgegevens van het kind bij online toezicht van ouders en gegevensuitwisseling in de jeugdzorg. Op het gebied van het strafrecht valt daarbij onder meer te denken aan een pleidooi voor een kindgerichte annak en alternatieven voor de politiecel, een artikel over factoren die de validiteit en betrouwbaarheid van verklaringen van kinderen in forensisch onderzoek beinvloeden, een bijdrage over herstelrecht en ten slotte een bijdrage over DNA-afname bij minderjarige veroordeelden. Ook het vreemdelingenrecht kwam aan bod met onder meer een artikel dat het juridische kader van staatloosheid voor kinderen in Nederland schetst aan de hand van het juridische kader en een recente casus. In het kader van het praktijkgerichte karakter past ook andacht voor andere disciplines dan de strikt juridische. In dat kader valt de bijdrage te plaatsen over de kansen en bedreigingen om tot een effectieve aanpak van schoolverzuim te komen en een eerste artikel van een tweeluik over een pilotanalyse naar ouderschapsbeoordelingen in jeugdbeschikkingen. Ten teken van het IVRK als leidend uitgangspunt bevat het tijdschrift ook een rubriek 'General Comments'. Daarin wordt steeds een van de General Comments van het VN-Kinderrechtencomité toegelicht en becommentarieerd. Er verschenen bijvoorbeeld bijdragen over General Comment nr. 1: de doelstellingen van onderwijs, over General Comment nr. 5: algemene maatregelen om het IVRK te implementeren en over General Comment nr. 12 over het recht om te worden gehoord.

Deze artikelen zijn nog te vinden op de website van OpMaat Jeugdrecht, https://opmaat.sdu.nl/jeugd recht.

Het eerste nummer van het nieuwe tijdschrift $T v f r$ verschijnt bij gelegenheid van het jaarlijkse seminar van het Centre for Children's Rights Amsterdam (CCRA). Het CCRA is een uit de bronnen van de Universiteit van Amsterdam ontstane stichting met een drieledige doelstelling: onderwijs, onderzoek en het bieden van een platform. Ook bij de activiteiten van het CCRA is het IVRK leidend. Dit gedeelde uitgangspunt heeft ertoe geleid dat er van meet af aan nauwe banden zijn geweest, eerst met $\mathcal{F I P}$ en nu met $T v \mathcal{f}$ r. Dit jaar wijdt het CCRA zijn jaarlijkse seminar aan uitspraken in kindvriendelijke taal. Daarbij komen bijvoorbeeld vragen aan bod als: gaat het om de hele uitspraak - moet het kind wel op deze manier geconfronteerd worden met de in geding zijnde conflicten - of volstaat een toelichting aan het einde van de uitspraak? Kinderen zijn immers formeel geen subject van recht in de procedure, maar in veel gevallen object van geschil op het strijdtoneel van de ouders. En leidt het terugbrengen van de uitkomst in 
een rechtszaak naar het kind inderdaad tot een betere acceptatie van de uitspraak? En moeten rechters worden geschoold op het gebied van kindvriendelijke taal?

Het jasje waarin het nieuwe tijdschrift wordt gestoken, verandert dan wel, maar inhoudelijk blijft de redactie op het ingeslagen pad doorgaan en dat - dankzij Boom juridisch - met hernieuwd enthousiasme.

Coby de Graaf en Esther Polhuijs 